\title{
POSSIBILITIES OF COSTS REDUCTION FOR CONSTRUCTION PROJECT REALIZATION IN YEMEN
}

\author{
Salem Khamis \\ Hadramout University of Science and Technology Faculty of \\ Engineering and Petrolium
}

(Received July 21, 2008 Accepted Augest 9, 2008)

The contribution contains partial results of the research focused on exploration of impacts influencing the overall amount of costs for construction of blocks of flats in Yemen.

These are mainly the following: placing the building in a particular locality, using local building materials and existing assortment of imported building materials (their characteristics and dimensions), using geological research when making design of building foundations, scheduling,etc. The designer must take these impacts into regard when making design of a building to decrease the costs for its construction as well as utilization. The performed research showed that for example by proper foundation in accordance with particular geological conditions there can be achieved a reduction of the overall costs for project construction even by $8.5 \%$, by proper selection of building material and and its better use (without excessive waste) up to $5 \%$ of total costs can be saved. The project must be executed in optimum time and using CPM methods up to $2.6 \%$ of total costs for project construction can be saved.

KEYWORDS : Costs, construction project, building materials, design preparation, economic efficiency.

\section{RESEARCH OBJECTIVE}

The aim is to point out possibilities of costs reduction for construction of blocks of flats, in particular by increasing quality of design and execution preparation. Therefore it is necessary to use qualified labour, proper building materials of good quality and provide high-quality and safe execution of construction work in the whole process of project preparation and realization. The measures improving investment process are aimed at the primary objective which is to achieve economic efficiency of flats construction projects.

\section{FOREWORD}

To have a house or flat is objective of each citizen, but high costs for construction of flats do not enable each family in Yemen to buy their own flat. Therefore the state must establish such conditions for entrepreneurs in construction business that these companies would be stimulated to execute the construction projects as cheap as possible ( e.g. competition, invitation for tenders). 
The task of civil engineering specialists is to look for methods to decrease total costs for construction projects. As an Arabic saying goes, need is the mother of discovery. Firstly the reasons for high costs of construction of flats must be found. We suppose that this problem can be solved mainly by designers in Yemen so that they will make an effort to eliminate factors causing increase of the construction costs. The designers must design each project taking into consideration the particular conditions of the building location and climatic conditions of the locality. It is inappropriate to make realization of the same project in mountains and by the sea, which happened in several cases. Furthermore, they should consider use of available building materials, dimensions of imported building materials on the market ( e.g. length of steel), make tests of load-bearing capacity of the soil, and accordingly design the foundations and make scheduling for project realization. If all the mentioned negative impacts meet in a project and they are not solved the total project costs will be increased by $20 \%$.

From the above reasons the research is focused on the issue of total costs increase for realization of construction project, or to find possibilities of their reduction. The aim is to achieve an economic project, which means to design and subsequently make realization of a construction project with the required efficiency, of high quality and long service life, in an optimum time and at the lowest possible costs. Not only reduction of one-time investments for project realization but also minimization of future operation costs and costs for repairs and maintenance during the service life of the building should be considered. Such project will be economic when we make an effort to minimize the total costs for its design, realization, as well as utilization.

The objective is that state should use the loan from finance development bank to build as many flats as possible instead of pulling down or reconstructing flats which are not even 50 years old because they were built in poor quality. Everyone of us knows that economy means good management to achieve profit in a company, the company should restore themselves, to go out from a closed circle and make development. We would like to say that to make project documentation taking into consideration its economic solution will help people to reduce flat acquisition costs and use natural resources in an optimum way which requires not much finance. The research is focused on two main factors influencing the costs for construction project :

1. Natural conditions (geological, climatic) at locality of construction project

2. Economic, architectonic and structural design of projects, ( economic solution of project documentation).

\section{NATURAL CONDITIONS AT CONSTRUCTION LOCALITY}

\subsection{Design}

The project documentation should take into consideration conditions of the project locality so that there should be created a comfortable interior environment for the dweller. This will reduce also the costs for building operation, e.g. energy consumption for lighting and air conditioning during the entire lifetime of the building. To save operation energy using industrially produced thermal insulation in flats is not only very expensive in practise, but also harmful for the environment. In this respect is therefore 
better to use natural insulation materials such as wood or clay. The architectonic design plays an important role in regard to reduction of material and energy consumption as well as amount of labour. For example if an architect designs height of windows $1.6 \mathrm{~m}$ instead of the commonly used height of $1.0 \mathrm{~m}$, wall lintel will be not necessary, and material as well as labour consumption will be reduced. The saved costs can be used for realization of other project parts.

Certainly, there are also design conditions which must be observed, such as :

For each room of a flat there are required temperatures defined by standard. In case that due to design the reached temperature in a room is higher by $10{ }^{\circ} \mathrm{C}$ than defined by standard there will be released harmful substances from the used chemical building materials to environment. The designer must observe conditions for the design as well as natural conditions resulting from construction locality to achieve lower energy consumption during the service life of the building.

The German research studies of 1978 proved that the consumed operation energy of a common flat for the period of 60 years was 3,300,000 kw/h and after the flat had been reconstructed using natural building materials the energy consumption was reduced to $600,000 \mathrm{kw} / \mathrm{h}$ [7]. This means that the monthly costs of consumed energy were reduced from 500 dollars to 72 dollars.

\subsection{Use of Local Building Materials}

The use of local building materials has an important impact on reduction of costs for a building project. In Yemen there is a big difference in costs for construction of blocks of flats, particularly in the region of Wadi Hadramoutu where clay as well as reinforced concrete flats are built. In 2000 clay blocks of flats were built for $13 \mathrm{D} / \mathrm{m} 3$ of built-up room and reinforced concrete blocks of flats for $35 \mathrm{D} / \mathrm{m} 3$ [2]. This means that a clay flat with the area of $150 \mathrm{~m} 2$ and clear height of $3.5 \mathrm{~m}$ was 6,835 dollars and a reinforced concrete flat 18,375 dollars excluding finishing work. From 2000 to 2006 the prices of steel and cement went up by $100 \%$, but prices of clay building materials increased only by $20 \%$ which means that the prices of the mentioned types of flats are the following:

1. clay flat with the area of $150 \mathrm{~m} 2$ is 8,400 dollars excluding finishing work

2. reinforced concrete flat with the area of $150 \mathrm{~m} 2$ is 36,750 dollars excluding finishing work

\subsection{The Question, Why Such a Big Difference?}

1. The production costs of building materials and their prices are affected mainly by theprices of raw materials from which they are produced, place of production and transport costs which are in case of imported raw material high. Selection of appropriate local natural raw materials would reduce energy consumption for production of building materials and affects also their prices. Local raw materials are easily accessible and do not imply such high transport costs which can be even $50 \%$ of total costs [7], because central production of local materials is not required. The construction projects using local materials such as stone, clay and wood have been successful in several Arabic states and did not require high costs for realization and it was easy to find quality labour in the process of construction. 
2. Natural material - local building material - the production costs are low, but the production costs will increase if other imported materials are used such as plaster or steel. The costs will increase most if complex building materials are used such as thermal insulation or multilayer walls. Instead of these materials, which are not produced in Yemen and are always imported, we can use lower-cost local building materials ofhigher quality.

3. Imported building materials such as aluminium and plastic materials which are on the market and are used to build blocks of flats might have good qualities such as high lifetime, easy maintenance, but they have prices higher even by $100 \%$ in comparison with the local building materials [7] such as wood.

4. All building materials imported from other states, which do not produce these materials, are even more expensive. It has been also proven that lifetime of building materials vary depending on the location where they are used. To achieve good economic results it is important to use an appropriate building material for particular natural conditions of the building location (e.g. by the sea external steel structures corrode rapidly).

\section{ECONOMIC SOLUTION OF PROJECT DOCUMENTATION}

\subsection{Dimensions of Constructional Elements}

Reduction of costs for construction project depends on quality of architectonic design and construction drawings. If an architect designs the layout and dimensions of individual constructional elements according to the length and surface of the existing building material, material waste will be reduced and also unit price will be lower. For example, if doors $2.2 \mathrm{~m}$ high and $1.2 \mathrm{~m}$ wide are manufactured according to an architectonic design and on the market there is only available a wooden board having dimensions $2 \mathrm{~m} * 2.25 \mathrm{~m}$, only one door can be manufactured and there will be waste of $0.8 \mathrm{~m}$ width. The door price would be then higher as if the whole board was used to manufacture door of $1.0 \mathrm{~m} * 2.2 \mathrm{~m}$ dimensions. If this economic method of design is used building material waste will be reduced and as a result also costs for the construction project will be lower, which sometimes make even $5 \%$ of the total costs for the construction project. The proof is given by the following example:

It is known that steel is mostly used in construction projects and has direct impact on the total costs, as reinforced concrete work represent approximately $15 \%$ of costs. Furthermore, steel is the most expensive building material and it is imported to Yemen. Its price was $560 \mathrm{D} / \mathrm{t}$ in 2005 and it goes up every year due to inflation.

The architect must take into consideration material assortment existing on the market in the layout design. E.g. dimensions of girders must suit the length of steel which is sold on the market only in $12 \mathrm{~m}$ length. Therefore I investigated, taking into regard this point of view, specific drawings of designed girders according to the execution project documentation of 2002. In this project documentation of a two-storey building of surface area $1,166.4 \mathrm{~m} 2$ and total costs 17,937 dollars, the width between supports is $3.6 * 5.4 \mathrm{~m}$. The calculation of girders armature is shown in the following tableNo.1 and layout of the girders is illustrated in figure No.1. 
Table No.1: Calculation of reinforced concrete girders

\begin{tabular}{|c|c|c|c|c|c|c|}
\hline Number & Girders & $\begin{array}{c}\text { Section } \\
\text { area }\end{array}$ & $\begin{array}{c}\text { Lower } \\
\text { armature }\end{array}$ & Bend armature & $\begin{array}{c}\text { Upper } \\
\text { armature }\end{array}$ & Stirrups \\
\hline 1 & $\mathrm{~B} 11, \mathrm{~B} 12$ & $30 \times 70$ & $7 \varnothing 16$ & $4 \varnothing 16$ & $8 \emptyset 16$ & $1 \varnothing 8 / 15 \mathrm{~cm}$ \\
\hline 2 & $\mathrm{~B} 21, \mathrm{~B} 22$ & $30 \times 80$ & $8 \varnothing 16$ & $4 \varnothing 16$ & $6 \varnothing 16$ & $1 \varnothing 8 / 15 \mathrm{~cm}$ \\
\hline 3 & B31,B32 & $30 \times 60$ & $6 \varnothing 16$ & $3 \varnothing 16$ & $4 \varnothing 16$ & $1 \varnothing 8 / 15 \mathrm{~cm}$ \\
\hline 4 & B41,B42 & $30 \times 35$ & $4 \varnothing 16$ & $3 \varnothing 14$ & $4 \varnothing 16$ & $1 \varnothing 8 / 15 \mathrm{~cm}$ \\
\hline 5 & B51,B52 & $30 \times 30$ & $4 \varnothing 14$ & $3 \varnothing 16$ & $4 \varnothing 14$ & $1 \varnothing 8 / 15 \mathrm{~cm}$ \\
\hline 6 & $\mathrm{R}$ & $30 \times 15$ & $2 \varnothing 14$ & $3 \varnothing 14$ & $2 \varnothing 14$ & $1 \varnothing 8 / 15 \mathrm{~cm}$ \\
\hline
\end{tabular}

The quantity and price of steel loss on reinforced concrete girders are calculated as follows:

\section{A) Quantity}

1. B1 girder is divided into B11 and B12, B12 length $=7.2 \mathrm{~m}$. If we know that steel length is $12 \mathrm{~m}$, then one bar will suffice only for one armature of B12 girder and there will be waste. The quantity of waste will be calculated as: steel length - (B12 length+bend length) $=12-7.5=\mathbf{4 . 5} \mathbf{~ m}$.

2. B2 girder is divided into B21 and B22, B21 length $=3.6 \mathrm{~m}$ and B22 length $=5.4 \mathrm{~m}$. In this case one bar will not suffice for three girders of B2 type, but only for two girders. So there will be waste of the following quantity: steel length - ( B22 length + B21 length + connection length + bend length $)=12-9.5=\mathbf{2 . 5} \mathbf{~ m}$.

3. B3 girder is divided into B32 and B31, B31 length $=5.4 \mathrm{~m}$ and B32 length $=7.2 \mathrm{~m}$. In this case B3 is the same as B1, so there will be waste of length $\mathbf{4 . 5} \mathbf{~ m}$.

4. B4 girder is divided into B42 and B41, B4 lengths are the same as B1, B3. There will be waste of length $\mathbf{4 . 5} \mathbf{~ m}$.

5. B5 girder is divided into B52 and B51, their lengths are the same as B2 lengths, therefore there will be waste of length $\mathbf{2 . 5} \mathbf{~ m}$.

The quantity of armature waste, i.e. loss of steel on all reinforced concrete girders is shown in the table No.2. Diameter of girders armature is $16 \mathrm{~mm}$.

Table No.2: Total length of armature waste of reinforced concrete girders in meters

\begin{tabular}{|c|c|c|c|c|}
\hline Girders & Number of girders & $\begin{array}{c}\text { Number of } \\
\text { armature }\end{array}$ & $\begin{array}{c}\text { Armature waste } \\
\mathbf{m}\end{array}$ & $\begin{array}{c}\text { Quantity } \\
\mathbf{m}\end{array}$ \\
\hline B1 & 19 & 14 & 4.5 & 1197 \\
\hline B2 & 8 & 20 & 2.5 & 400 \\
\hline B3 & 12 & 13 & 4.5 & 702 \\
\hline B4 & 4 & 11 & 4.5 & 198 \\
\hline B5 & 4 & 11 & 2.5 & 110 \\
\hline \multicolumn{4}{|r}{} \\
\hline
\end{tabular}

The designed block of flats has two storeys, therefore the total quantity of armature waste is: $2607 * 2=5214 \mathrm{~m}$.

\section{B) Price}

It is known that the 2005 price of steel was 560 dollars per tonne. Weight of $16 \mathrm{~mm}$ diameter armature is $1.81 \mathrm{~kg} / \mathrm{m}$. The total price of armature waste $=5214 * 1.81 *$ $0.560=5285 \mathrm{D}$. 
In the above example I found out that the total price of armature waste amounted to $7 \%$ of reinforced concrete work, which was 77,854 dollars and represented $3 \%$ of total costs for construction project. Note! The calculated price is based on steel loss on girders, which are an integral part of reinforced concrete work including also reinforced conctrete slabs, columns, bearers, foundations, etc.

It follows that architectonic design must take into consideration existing dimensions of building material to achieve reduction of the presumed loss of $5 \%$ of the total costs of construction project.

\subsection{Foundation of Buildings}

It is known that the calculation of building foundations is based on calculation of live and dead loads of the building and bearing capacity of subsoil. From engineering point of view there must not be used the same model of foundations at different places of construction, at which there are usually different foundation conditions. The research proved that there are big differences in costs for foundation of individual buildings. Execution of foundations which were not dimensioned and designed according to the calculation of loads and bearing capacity of subsoil increase costs of construction project. The proof is shown by the example of execution project of 2001. It was a fourstorey school building with total floor area of $1,252 \mathrm{~m} 2$, the total costs 288,410 dollars. [1]

The building was founded on strip foundations. The soil bearing capacity was $1 \mathrm{~kg} / \mathrm{cm} 2$, precise calculations of loads in accordance with Arab standards brought down the load by $20 \%$ which meant that instead of foundation strips there could be used foundation footings with lower costs. The difference in costs for foundation strips and footings is shown in the table No.3.

Table No.3 Costs for foundation strips and footings

\begin{tabular}{|l|l|l|}
\hline Foundation type & Footings & Foundation strips \\
\hline Reinforced concrete & $100 \mathrm{~m} 3$ & $218.3 \mathrm{~m} 3$ \\
\hline Steel consumption & $72 \mathrm{~kg} / \mathrm{m} 3$ & $127.9 \mathrm{~kg} / \mathrm{m} 3$ \\
\hline Costs in dollars & $100 * 131.48=13,148$ & $218.3 * 172.85=37,733.2$ \\
\hline
\end{tabular}

Note:

In the above table there is shown calculation of costs for foundation footings and strips. The calculation is based on the price of $1 \mathrm{~m} 3$ of reinforced concrete foundations containing $100 \mathrm{~kg}$ of steel, which is 152.2 dollars, while price of steel is 0.74 dollar $/ \mathrm{kg}$. The unit prices of reinforced concrete foundations vary depending on quantity of used steel. It follows that $1 \mathrm{~m} 3$ of foundation footings containing $72 \mathrm{~kg}$ steel have unit price 131.48 dollars and price of $1 \mathrm{~m} 3$ of foundation strips containing $127.9 \mathrm{~kg}$ of steel is 172.85 dollars. These prices are on 2001 price level.

In the table No.3 there is shown that costs for reinforced concrete foundation footings are 13,148 dollars and costs for foundation strips are 37,733.2 dollars. The difference is $24,588.2$ dollars. The costs for all reinforced concrete work are 98,581 dollars and total costs for the building are 288,410 dollars. It means that using footings instead of strips would reduce the costs for reinforced concrete work by $24 \%$ and the total costs for the building by $8.5 \%$. 
Solution of the mentioned example can be made also in a different way which would be using foundation footings with connecting strips of dimensions $35 * 100 \mathrm{~cm}$ between footings which would prevent sinking of the building. Using footings with connecting strips instead of foundation strips would reduce the costs as shown in the following table.

Table No.4: Costs for foundation on footings with connecting strips and on foundation strips

\begin{tabular}{|l|l|l|}
\hline Foundation type & $\begin{array}{l}\text { Footings with connecting } \\
\text { strips }\end{array}$ & Foundation strips \\
\hline Reinforced concrete & $109.16 \mathrm{~m} 3$ & $218.3 \mathrm{~m} 3$ \\
\hline Steel consumption & $96.8 \mathrm{~kg} / \mathrm{m} 3$ & $127.9 \mathrm{~kg} / \mathrm{m} 3$ \\
\hline Costs in dollars & $109.16^{*} 143.1=15,621$ & $218.3 * 172.85=37,733.2$ \\
\hline
\end{tabular}

In Table No.4 there are calculated costs for foundation on footings with connecting strips amounting to 15,621 dollars and costs for foundation strips are $37,733.2$ dollars. The difference is $22,112.2$ dollars representing $22.4 \%$ of costs for reinforced concrete work and $7.7 \%$ of total costs for the building.

\subsection{Time Schedule of Construction Project}

It is known that complex construction project documentation (drawings) requires longer period of realization than a simple one which results also in higher costs for realization. There is some dependence between construction period and costs for realization.

From technical point of view realization of construction project can be made in minimum time, but it would mean higher costs due to use of e.g. modern technologies, or more workers etc. In normal situation realization of construction project is made in optimum time which brings minimum costs. If the optimum time period of realization is prolonged it will cause increase of, in particular, overheads, but also probably of direct costs for materials such as steel and cement prices of which in Yemen increased from 2000 to 2006 by $100 \%$.

By the following example it is illustrated what influence has time planning on costs. There is realization project of 2004 (Technical Faculty in Yemen) total costs of which are 13 mil.dollars, total floor area of $36,178 \mathrm{~m} 2$ and planned time for realization four years.

I examined what would be optimum time for realization of the mentioned project which consists of five buildings. I used CPM method and sequential problem solution. I found out that this project can be realized in 3 years and 7 months which would be shorter by 20 weeks. [3]

It is known that labour and operating costs are $25 \%$ of total costs [4], i.e. $3,250,000$ dollars. If weekly labour and operating costs (overheads) are 16,927 dollars, for 20 weeks there will be saving on costs of 338,540 dollars, i.e. $2.6 \%$ of total costs. This proves that time planning has remarkable impact on reduction of costs for a construction project, but in spite of this fact construction companies in Yemen do not consider time planning important.

Finally it can be said that this article has been rather abbreviated, however, we tried to express clearly the objective of our research which is looking for possibilities 
of total costs reduction for realization of construction project. Besides the reasons mentioned in the article there are also other reasons of costs increase for construction project such as land price, clear height of a floor and others which should be solved in future.

\section{RESEARCH RESULTS}

1. Clay houses are cheaper approximately by $400 \%$ in comparison with reinforced concrete flats. The proof of this fact is the mentioned example of construction of flats with the surface area of $150 \mathrm{~m} 2$ in the city of Wadi Hadramout in Yemen in which the price of clay flat is 8,400 dollars and a reinforced concrete flat is 36,750 dollars excluding finishing work.

2. In the project documentation (drawings) taking into consideration the existing assortment of material on the market such as steel, the total costs of construction project were reduced by $3 \%$ due to reinforced concrete girders solution.

3. Foundation footings and footings with connecting strips are more efficient than foundation strips. Due to using foundation footings instead of strips $8.5 \%$ of total costs were saved and using foundation footings with connecting strips instead of foundation strips saved $7.7 \%$ of total costs.

4. By using CPM method and sequential problem solution in time planning about $2.6 \%$ of total costs can be saved.

5. Finally, it can be stated that the total costs of construction project will be lowered by $16.1 \%$ if the project documentation takes into consideration dimensions of the existing building material available on the market, real bearing capacity of subsoil, and optimum time for construction is determined.

\section{RECOMMENDATION}

I recommend to appoint an expert commission to check the project documentation before the tenders for building contractors are invited. The objective is to evaluate the economic aspect of the project documentation.

\section{LITERATURE:}

[1] Bitar, Sameh Abdulaziz.Tatbig Al code Al Masri wa tathiroh ala Al taklufa Al egtisadia v Al Madares. (Application of Egiption Code and Cost of Schools). Conference of Arabic Code and Collection of Arabic Economics in Engineering Branch, Cairo,p,251-261.2003.

[2] Bin Shamleh, Salem Khamis. Altin wa Al Egtisad ( Caly and Economics). Journal of Member of Hadramout University of Science and Technology. Edetion 6,p.3.2000.

[3] Bin Shamleh, Salem Khamis. Al pornameg Al zamany Itanfid Al Mabany. ( The Time program of Relation Building. Journal of Aden University of Application Science. Edition 9.N.3.p.453-468.2005 
[4] Bollová, Gabriela: Calculations. Faculty of Civil Engineering, STU, Bratislava,Slovakia, 1989

[5] Helal, Muhamed Sameh, Backaground of concret. The world of books 1993.

[6] Majduch,D., Harvan,I., Fillo,I., : Design of Concrete Structures in Practice. Faculty of Civil Engineering, STU, Bratislava,Slovakia, alfa Bratislava 1991.

[7] Nasir, Nadia Muhamed. Osos Ekhtiar mawad Albinaa. (Backaground of Building Materials.Conference of Arabic Material of Building and Economic, Cairo p.9891001.2000.

[8] Zien Al-abedin, Habib Mustava. (Asasiat Alkharasana Almusalaha. (Concrete of Building). Company of Baabaki.1997.

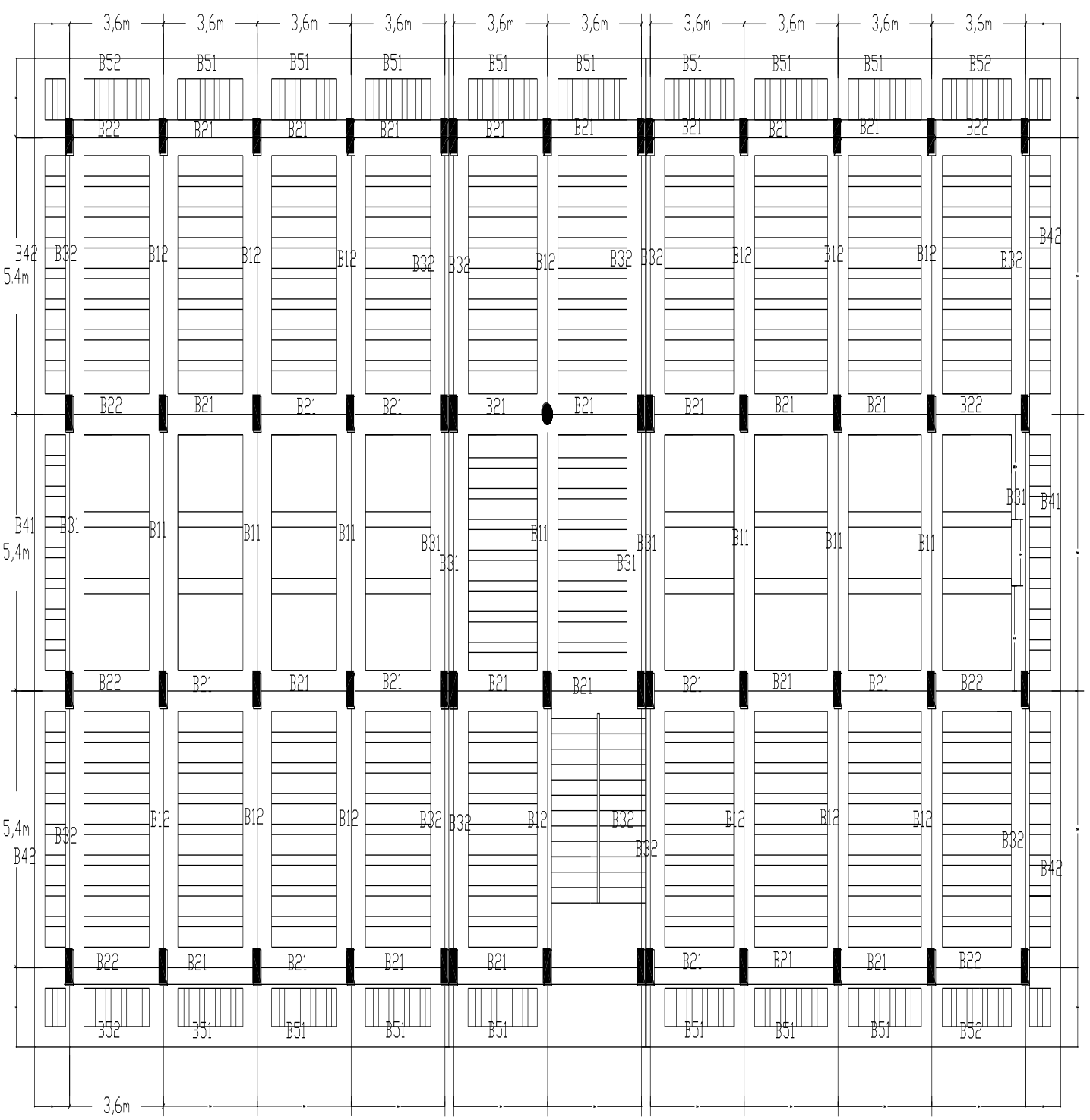

Figure No. 1: Layout of girders in project documentation of a block of fla 


\section{إمكانيات خفض تكلفة مشروعات إنشاء المباني المقامة باليمن \\ دسالم خميس بن شمله}

كلية الهندسة والبترول . جامعة حضرموت للعلوم والتكنولوجيا

ترجع أهمية البحث الي دراسة العوامل المؤثرة جزئياً على التكلفة الكلية على بلوكات المباني السكنية

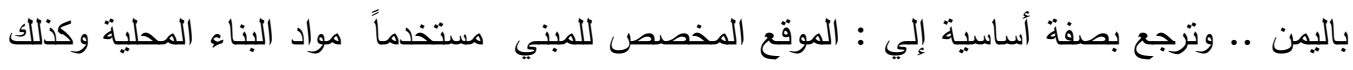

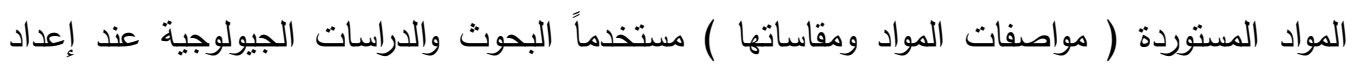

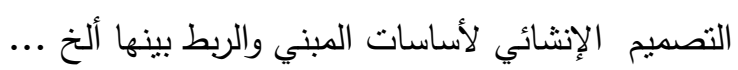

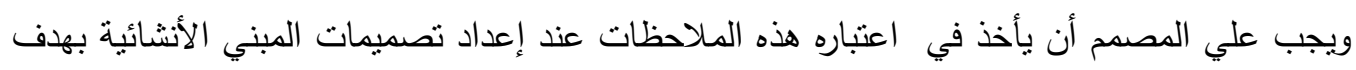
تخفيض تكلفة المبني طبقاً للاستخدام الوظيفي .. والبحث يلقي الضوء كمثال على أساسات مبني قائم بالحالة الجيولوجية الخاصة بالموقع والتي تئكد خفض التكلفة الاجمالية ( الكلية) للمشروع بحوالي 5

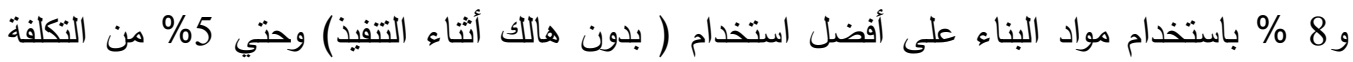

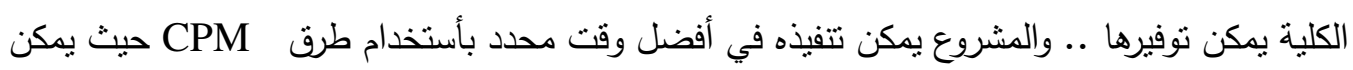
توفير 2 6و من التكلفة الكلية للمشروع • 